\title{
COMPARITIE STUDY ON DIFFERENT MIXTURES OF SILAGES ON MILK PRODUCTION, RUMEN AVTIVITY AND PERFORMANCE OF BORN KIDS IN DAIRY ZARIBI GOATS .
}

Saleh, M. R.M.

Animal Production Res. Institute, Agric .Research Center, Dokki, Egypt.

\begin{abstract}
The aim of this study was to investigate milk yield, milk composition and rumen activity of Zaribi does and performance of their newly born kids when were fed different silage mixtures. Eighteen Zaribi dairy goats showing healthy were divided into three similar groups ( 6 animal each ) with average body weight $39.87 \mathrm{~kg}$ and nearly 30-36 months of age, every kids with their dams (average BW $3.60 \mathrm{~kg}$ ). All animals were fed concentrate feed mixture (CFM) to cover $40 \%$ of requirements recommended by $N R C$ (1981). Besides ad libitum berseem silage offered to $\mathrm{R}_{1}$, silage of berseem $x$ Raygrass for $R_{2}$ and silage of berseem $x$ Rodgrass for $R_{3}$. The experiment lasted for 120 day.Nutrient digestibility and nutritive value were determined by digestibility trials. The obtained results of saponine residues in rations, milk, feces, urine and rumen liquor showed that there significantly $(P<0.05)$ higher with $R_{1}$ group of all parameters than other tested groups. Moreover,feed intake of $R_{2}$ and $R_{3}$ groups were significantly $(P<0.05)$ higher compared with $R_{1}$.As for digestion coefficients the results were revealed that all nutrients digestibility were increased gradually with $R_{2}$ and $R_{3}$ in comparison of $R_{1}$. But no differences were observed of feed intake and digestion coefficients between $R_{2}$ and $R_{3}$ groups. Addition to Water consumption recorded lower values with $R_{2}$ and $R_{3}$ groups than control $\left(R_{1}\right)$. Ruminal $\mathrm{pH}$, VFA's and ammonia- $\mathrm{N}$ concentrate were recorded the highest values at $3 \mathrm{hrs}$ post feeding.Molar proportion of ruminal volatile fatty acid (VFA's) found that there variations between acetic, propionate, butrtate and Iso-Biotrate values and the $R_{2}$ results showed that there significant $(p<0.05)$ decrease in acetic, butrtate and isobiotrate than those of $R_{1}$ and $R_{3}$, as same time the propionate and valerate were gave higher value with $\mathrm{R}_{2}$ group. Milk production as affected experimental rations showed that there were significant differences $(p<0.05)$ in milk composition among the different tested groups. And the daily milk yield of $R_{2}$ and $R_{3}$ were significantly $(p<0.05)$ higher than $R_{1}$.Data of kids $B W G$ sucking their mother milk illustrated that $R_{2}$ and $R_{3}$ groups were significantly $(p<0.05)$ increased compared to those in $R_{1}$ group. Thereafter the second group was recorded higher value of the total viable bacteria count than first and third groups. Economical efficiency of kids body gain, milk yield of dairy Zaribi goats based upon the differences in both growth rate and total cost.The corresponding values of the economical efficiency were $100 \%, 123 \%$ and $119 \%$ for $\mathrm{R} 1, \mathrm{R} 2$ and $\mathrm{R} 3$ respectively.
\end{abstract}

Keyword : Different type of silages, dairy goats, milk production and constituents, performance of born kids, rumen activity and economic efficiency.

\section{INTRODUTION}

Earlier experiments have established the high intake and milk production potential of legume silages. (Castle et al.,1983) and (Auldist et al.,1999) showed the high feeding value of clover silage for dairy goats (Thomas et al.,1985).Other studies with red clover and alfalfa have demonstrated the superiority of legume silages in comparison with grass 
silages (Hoffman et al., 1998). Shortage of the concentrate feed in Egypt is a well known problem,therefore several studies were carried out to improve the nutritive values of the preserved mixture of green forages on the form of silage or hay to increase feed quantity and participate in solution of feed shortage problem and the dramatic increase in prices of animal feed ingredients .In Egypt, sheep and goats are less developed compared to other livestock and the commercial goat's production is an intensive basis and commercial for feed resources with human. The ruminant in Egypt was predicated to be as 10.8 million animal unites in year 2010.This animals required about 15.8 million tons of TDN and 2.49 million tones of DCP (Abdelhamid et al.,2001).The available conventional feed resources could cover only $84 \%$ and $89 \%$ of the required TDN and DCP, respectively (Abou Akkada 1984).However, feeding Egyptian berseem in green forage crops mixtures led to Saponine as considering anti nutritional factor and affected performance of ruminants and pigs (Patil et al.,1972).Harmful of saponine effect on cell membranes permeabilisation and other membrane. Saponins have long been known to action on erythrocyte membranes and this property has been used for their detection, (Plock et al.,2001).

The aim of the study is to investigate the effect of feeding the different silage mixtures types on milk yield, milk composition and rumen activity in Zaribi does and performance of their newly born kids.

\section{MATERIALS AND METHODS}

This study was conducted to evaluate the effect of mixtures of green forages on milk production, ruminal microorganisms activity and body gain of born kids sucking their mother milk in dairy Zaribi goats.

\section{Experimental animals and rations}

Eighteen Zaribi dairy does were divided into three similar groups $(6$ animal each) with average body weight $39.87 \mathrm{~kg}$ and nearly $30-36$ months of age,every kid with her dam (average BW $3.60 \mathrm{~kg}$ ). Each group was housed in a separate wall-ventilated pen. Animals were weighed at the beginning and at biweekly intervals thereafter. All animals were fed concentrate feed mixture (CFM)to cover $40 \%$ of requirements recommended by NRC(1981).Besides ad libitum berseem silage to $R_{1}$, silage of berseem $\times$ Raygrass for $R_{2}$ and silage of berseem $x$ Rodgrass for $R_{3}$. Daily rations were offered to animals in two equal meals at 8 am and 4 pm.Feed intake and feces were recorded daily,Chemical analysis of the concentrate feed mixture,EBSxRay grass and EBSxRod grass and experimental rations are shown in(Table1).Clean water was permanently available throughout the experimental period to provide the production requirements. Whereas the feed and water consumption was daily measure-ed.Feed samples were prepared and keep for analyzed.Concentrate feed mixture.(CFM) consists of $36 \%$ yellow corn, $30 \%$ undecortecated cotton seed, $27 \%$ wheat bran,3.0\%molasses, $2.5 \%$ limestone, $1 \%$ common salt and $0.5 \%$ minerals mixture. 


\section{Feces and urine collection}

At experiment end three animals from each group were chosen and put in digestion boxes preliminary to feces and urine collection. The collection period was 7 days following a two weeks as preliminary period, the feces samples were collected quantities daily during the collection period. Representatively samples of fresh feces were dried and ground then mixed and kept for chemical analysis. Whereas the urine was measured daily and collected after diluted with $20 \mathrm{ml}$ of conc. sulfuric acid to kept ammonia messed until nitrogen determining.

\section{Rumen liquor samples}

Rumen liquor samples were collected at the end of the digestibility trials using a rubber stomach tube before feeding $(0 \mathrm{hr}), 3$ and 6 hrs postfeeding .Rumen liquor samples were strained through four layers of cheese cloth at each samples time for immediate determination of rumen digital $\mathrm{pH}$ meter. Ammonia- $\mathrm{N}$ was determined in rumen liquor according to(Conway 1962). Total volatile fatty acids concentrations were determined in rumen liquor according to(Warner 1964).

\section{Silage making}

Silage was made from green forages were chopped $(10-15 \mathrm{~cm})$ and sun dried to reach a moisture content of about $65-70 \%$,the silage was prepared by filling successive layers of the shopped materials and heavy trodden before adding the next layers. However, each layer was included the chopped Ray grass and Rod grass with berseem (1:1 on DM bases). All silages were put in plastic bags for 8 weeks.(Soliman,1997).

\section{Blood samples}

Blood samples were collected from the jugular vein once before feeding ( 3 animals from each treatment) at the end of feeding trials. Blood samples were centrifuged at $4000 \mathrm{rpm}$ for 20 minutes.Part of the separated serum was directed to enzymes activity determination, while the other part was stored frozen at $-20 c^{0}$ till the biochemical analysis. Commercial kits were used for colorimetric biochemical determinations.

\section{Economics efficiency}

Economics efficiency are calculated on bases of Selling income of (milk+ income of BWG)-coast of feed intake as following :

1-Feed cost / Kg gain (LE) = Total feed cost (LE) / BWG ( kg )

2-Income over feed cost $(\mathrm{LE})=\{$ (milk production $(\mathrm{kg}) \times$ price $(\mathrm{LE})+$ body weight gain $x$ price(LE) -Total feed cost (LE) Aboul Ella (2000), where price of one ton CFM $=2300 \mathrm{LE}$, rice straw $=80 \mathrm{LE}$, berseem hay $=800 \mathrm{LE}$, rod grass $=140 \mathrm{LE}$, ray grass $=140 \mathrm{LE}$, milk $=5 \mathrm{LE}$, price of $1 \mathrm{~kg}$ live bod weight $=25 \mathrm{LE}$ as the dominant market price in this period .

\section{Chemical Analysis}

Analyses of ingredients, CFM, Egyptian berseem (EB),rations and feces were carried out according to(A.O.A.C.2000).Fiber fractions were determined according to (Analyses of ingredients, CFM, Egyptian berseem (EB),rations and feces were carried out according(Goering and Van Soest, 1970).Plasma biochemical analysis were done using Biomerieux reagent kits. 
bilirubin(Monnet 1963)Milk fat total protein, total solid, solid not fat and ash were determined according to( Ling1963). Plasma samples were used for determination of total protein( Weichselbaum ,1989), albumin(Doumas et al.,1971), liver enzymes(Reitman and Frankle1957)urea (Patton and Crouch 1977), creatinine(Bartil et al.,1971), bilirubin(Elveback,1970), Whereas hemoglobin , haematocrite(Linne and Ringsrud1992)and Saponine Oleszek (2002).

\section{Statistical analysis}

Statistical analysis of data was performed using SAS(2003) procedures for personal computer, and the significant differences among means were detected by Duncans multiple range test (Duncan 1955) .

\section{RESULTS AND DISCUSSION}

\section{Chemical composition}

The chemical composition and fiber constituents of the feed ingredients and the experimental rations are presented in Table(1).The results showed that Ray grass $\left(R_{2}\right)$ and Rod grass $\left(R_{3}\right)$ were higher content of $C P$,CF ,EE and Ash than control group(R1).Furthermore NFE was higher with $\mathrm{R} 1$ compared to $\mathrm{R}_{2}$ and $\mathrm{R}_{3}$ groups. In addition to the fiber fractions as well as NDF,ADF and hemicellulose were higher for $\mathrm{R}_{2}$ and $\mathrm{R}_{3}$ rations.Some studies reported that forages in rations should never exceed more $44 \%$ of NFC or contain less than $15 \%$ NDF.The voluntary intake of feed depends essentially on the rate of degradation of its digestible matter into particles of a size small enough to enable their passage from the reticule-rumen to the lower gut.

Table ( 1 ) : Analysis of Ingredients and experimental rations fed by lactating Zaribi goats (\%on dry matter basis).

\begin{tabular}{|c|c|c|c|c|c|c|c|}
\hline \multirow{2}{*}{ Items } & \multicolumn{4}{|c|}{ Ingredients } & \multicolumn{3}{|c|}{ experimental rations } \\
\hline & C FM & BS & RYE & ROD & $\mathbf{R}_{3}$ & $\mathbf{R}_{\mathbf{2}}$ & $\mathbf{R}_{1}$ \\
\hline DM & 90.27 & 88.56 & 87.65 & 89.74 & 90.68 & 87.92 & 89.17 \\
\hline OM & 89.70 & 88.58 & 88.41 & 90.07 & 89.78 & 88.56 & 87.03 \\
\hline $\mathrm{CP}$ & 13.79 & 13.16 & 17.84 & 14.09 & $14.16^{\mathrm{B}}$ & $17.39^{A}$ & $16.58^{A}$ \\
\hline $\mathrm{CF}$ & 12.50 & 25.14 & 26.74 & 28.63 & $16.34^{\mathrm{B}}$ & $22.54^{\mathrm{A}}$ & $21.01^{\mathrm{A}}$ \\
\hline EE & 1.80 & 2.59 & 3.64 & 2.93 & $2.59^{\mathrm{B}}$ & $3.69^{A}$ & $2.88^{\mathrm{A}}$ \\
\hline $\mathrm{ASH}$ & 10.30 & 11.42 & 11.59 & 9.93 & $10.22^{\mathrm{B}}$ & $11.44^{\mathrm{A}}$ & $12.97^{\mathrm{A}}$ \\
\hline NFE & 61.61 & 47.69 & 40.19 & 44.42 & $56.69 A$ & $44.94 \mathrm{~B}$ & $46.56^{A}$ \\
\hline DCP & - & - & - & - & $10.14^{\mathrm{B}}$ & $13.38^{\mathrm{A}}$ & $12.49^{A}$ \\
\hline SE & - & - & - & - & $62.51^{\mathrm{A}}$ & $61.17^{\mathrm{B}}$ & $60.10^{\mathrm{B}}$ \\
\hline TDN & - & - & - & - & $64.27^{A}$ & $62.41^{\mathrm{B}}$ & $61.74^{\mathrm{B}}$ \\
\hline \multicolumn{8}{|c|}{ celluloses fractionation } \\
\hline \multicolumn{4}{|l|}{ NDF } & \multicolumn{2}{|c|}{\begin{tabular}{l|l} 
& $43.29^{\mathrm{B}}$ \\
\end{tabular}} & $44.17^{\mathrm{A}}$ & $45.63^{A}$ \\
\hline \multicolumn{4}{|l|}{ ADF } & \multicolumn{2}{|c|}{$32.16^{\mathrm{B}}$} & $33.47 \mathrm{~A}$ & $35.94^{A}$ \\
\hline \multicolumn{4}{|l|}{ ADL } & \multicolumn{2}{|c|}{10.07} & 10.16 & 10.65 \\
\hline \multicolumn{4}{|c|}{ Hemicelluloses } & \multicolumn{2}{|c|}{$11.13^{\mathrm{A}}$} & $10.70^{\mathrm{B}}$ & $9.69^{\mathrm{B}}$ \\
\hline Cellul & & & & & & $23.31 \mathrm{~A}$ & $25.29^{A}$ \\
\hline NFC & & & & & & $24.31^{\mathrm{A}}$ & $20.94^{B}$ \\
\hline UNDF & & & & & & 6.62 & 7.82 \\
\hline ANDF & & & & & & 32.52 & 29.81 \\
\hline NDS & & & & & & 60.86 & 62.37 \\
\hline RAC & & & & & & 48.53 & 47.91 \\
\hline
\end{tabular}


$A$ and $B$ Means having different superscripts within the same row are significantly different at $(P<0.05)$.

\section{Saponines residues}

Saponines residues was determined by method of Oleszek (2002) in both rations, milk, feces, urine and rumen liquor Table(2).Data showed that Saponines of $R_{1}$ were significantly $(P<0.01)$ higher for ration, milk, blood, rumen liquor ,feces and urine than other rations .Saponins more action on cell membranes and hemolytic action on erythrocyte membranes (El-Izzi et al.,1992,Authi et al.,1988,Menin et al.,2001). Also the Saponines has harmful damage in enzymes action and have toxic effects because Saponines are inhibition of cholinesterase isoenzymes in vitro and in vivo. Moreover Saponines is a poison associated with animal rations and toxic glycoside in Egyptian berseem, medicago sativa and sugar beet. (Plohmann et al.,2008) reported that Saponines has enhancement effect to the Humeral immune response on blood cells, it defects the protein digestibility and growth performance this data was obtained by (Plock et al.,2001,Choi et al.,2001) .

Table (2) : Saponine in both rations, milk, blood, rumen liquor, feces and urine fed by lactating Zaribi goats fed experimental rations .

\begin{tabular}{|l|c|c|c|}
\hline \multirow{2}{*}{ Items } & $\mathbf{g} / \mathbf{1 0 0} \mathbf{~ g m . ~})$ & $\mathbf{R}_{\mathbf{3}}$ \\
\cline { 2 - 4 } & $\mathbf{R}_{\mathbf{1}}$ & $\mathbf{R}_{\mathbf{2}}$ & $88.84^{\mathrm{B}}$ \\
\hline Rations & $146.2^{\mathrm{A}}$ & $84.67^{\mathrm{B}}$ & $17.59^{\mathrm{B}}$ \\
\hline MILK & $22.47^{\mathrm{A}}$ & $14.41^{\mathrm{B}}$ & $15.59^{\mathrm{B}}$ \\
\hline Blood & $25.66^{\mathrm{A}}$ & $13.39^{\mathrm{B}}$ & $36.07^{\mathrm{B}}$ \\
\hline Rumen liquor & $39.58^{\mathrm{A}}$ & $32.19^{\mathrm{B}}$ & $7.38^{\mathrm{B}}$ \\
\hline Feces & $29.52^{\mathrm{A}}$ & $7.34^{\mathrm{B}}$ & $6.27^{\mathrm{B}}$ \\
\hline Urine & $24.11^{\mathrm{A}}$ & $5.89^{\mathrm{B}}$ & signicantly \\
\hline
\end{tabular}

$A$ and $B$ Means having different superscripts within the same row are significantly different at $(P<0.01)$.

\section{Silage quality}

Data in Table(3) showed that the silage of $\mathrm{R}_{2}$ and $\mathrm{R}_{3}$ rations had good quality of the tested parameters as well as $\mathrm{pH}$, ammonia- $\mathrm{N}$,lactic acid and TVFA. Addition to increase value of protein and CF values and decrease of ash and NFE than control group Table (1).These results are in agreement with those reported by Abou-Akkada and Nour(1986), they indicated that the ensilage can preserve feed and improve its feeding value.

Table( 3) : Mean values of quality parameters of mixtures silages .

\begin{tabular}{|l|c|c|c|}
\hline Items & $\mathbf{R}_{\mathbf{1}}$ & $\mathbf{R}_{\mathbf{2}}$ & $\mathbf{R}_{\mathbf{3}}$ \\
\hline $\mathrm{pH}$ value & 4.37 & 4.82 & 4.49 \\
\hline Ammonia-N(mg/100g ) & $23.10^{\mathrm{B}}$ & $24.59^{\mathrm{A}}$ & $24.36^{\mathrm{A}}$ \\
\hline Lactic acid(mg /100g) & 3.28 & 3.96 & 3.59 \\
\hline TVFA( ME q /100g ) & $19.92^{\mathrm{B}}$ & $21.44^{\mathrm{A}}$ & $20.78^{\mathrm{B}}$ \\
\hline
\end{tabular}

$A$ and $B$ Means having different superscripts within the same row are significantly different at $(P<0.05)$.

Average daily feed intake

The criteria of dairy Zaribi goats fed different experimental rations are shown in Table(4).Group 1 had significantly $(p<0.05)$ higher of DM intake compared to others.as same time no significant differences observed between $R_{2}$ and $R_{3}$ groups.Furthermore the water consumption was 
Saleh, M . R . M .

decrease and recorded differences $(p<0.05)$ lower with $R_{2}$ and $R_{3}$ groups in protein level and lower value of saponines content than those in $\mathrm{R}_{1}$. 
Table(4): Feed intake and water consumption of lactating goats fed mixtures silages .(on DM basis) .

\begin{tabular}{|l|c|c|c|}
\hline Items & $\mathbf{R}_{\mathbf{3}}$ & $\mathbf{R}_{\mathbf{2}}$ & $\mathbf{R}_{\mathbf{1}}$ \\
\hline Body weight (kg) & 40.10 & 39.65 & 38.82 \\
Body weight $^{0.75}$ & 15.93 & 15.80 & 15.55 \\
\hline DMI (gm /day/d ) & $1958^{\mathrm{A}}$ & $1759^{\mathrm{B}}$ & $1824^{\mathrm{B}}$ \\
\hline DMI As\% BW & 4.88 & 4.44 & 4.70 \\
\hline $\left.\mathrm{DM} \mathrm{I} \mathrm{(gm} \mathrm{BW}{ }^{0.75}\right)$ & $122.8^{\mathrm{A}}$ & $111.33^{\mathrm{B}}$ & $117.30^{\mathrm{A}}$ \\
\hline CPI (gm /day/d ) & $27.73^{\mathrm{B}}$ & $28.83^{\mathrm{B}}$ & $30.24^{\mathrm{A}}$ \\
\hline DM intake / kg MILK & 1.33 & 1.10 & 1.13 \\
\hline Water consumption (MI/h/day) & $2294^{\mathrm{A}}$ & $2143^{\mathrm{B}}$ & $2068^{\mathrm{B}}$ \\
\hline
\end{tabular}

$A$ and $B$ Means having different superscripts within the same row are significantly different at $(P<0.05)$.

\section{Digestion coefficients}

Data of digestibility coefficients are presented in Table(5).The obtained results revealed that the DMI was decreased with $R_{2}$ and $R_{3}$ than $\mathrm{R}_{1}$.Moreover,the $\mathrm{OM}$ of $\mathrm{R}_{1}$ ration was less digested and increased gradually with R2 and R3 than R1 . Subsequently, except of DM and OM observed that forages mixtures silage(FMS)in lactating Zaribi goats rations resulted in better digestion coefficients for $\mathrm{R}_{2}$ and $\mathrm{R}_{3}$ groups of all digestion nutrients parameters than $\mathrm{R}_{1}$ ration, and results were clearly that CP digestibility was increased with higher protein rations $R_{2}$ and $R_{3}$. This are in agreement with those reported by Leupp(2008). On the other side the fiber constituents data Indicated that digestibility coefficients of $R_{2}$ and $R_{3}$ groups were increased linearly with rations contain higher fiber level as well as Ray grass and Rod grass silages at all cell wall constituents. This may be due to the low concentration of $A D L$ and the increase in ruminal fiber digestion that may occur with decrease of ADF content with control ration compared to second and third groups which resulted in an increase in rate of passage of digest from the rumen.(Weimer et al.,1999) they reported that increased dietary NFC is often observed to depress fiber digestion partly by depressing ruminal $\mathrm{pH}$.(Hall,2001)reported that construction of ruminant rations must has potentially higher digestible fiber and non fiber carbohydrate contribution to the ration. Furthermore, the Energy concentration (ME,DE,GE and NE) of second and third rations were higher in all energy values .

\section{Nitrogen utilization}

As show in Table(6).Nitrogen intake(NI), nitrogen excretion(NE)and nitrogen digestion were increased with $R_{3}$ group than $R_{1}$ and $R_{2}$.nitrogen retention(NR) was recorded higher value for second and third experimental groups $\left(R_{2} \& R_{3}\right)$ with higher differences as a reflection of DM intake. However, fecal nitrogen (NE) was decrease with $R_{1}$ and $R_{2}$,as same time the urine nitrogen was significantly $(p<0.05)$ higher with $R_{1}$ and $R_{3}$ rations compared to R2. This may be due back to increase of nitrogen utilization and high retention and laxative effect reported by(Al-Yousef et al.,1994).Moreover, the high level of nitrogen free extract and nitrogen intake in $R_{1}$ and $R_{3}$ rations gave fast fermentation carbohydrate which can couple the fast degradation of urea in this ration.Hence the production of ammonia can be efficiency used in building microbial protein rather than adsorption from rumen wall so the level 
of urinary excretion decreased with $\mathrm{R}_{2}$ group.Nitrogen balance as percentage of $\mathrm{NI}$ had differ significantly $(p<0.05)$ increase among $\mathrm{R}_{2}$ and $\mathrm{R}_{3}$ rations than $R 1$.This may be a reflection to the higher $C P$ digestibility in $R_{2}$ and $R_{3}$ compared to control ration.In accordance with the present results,(Mohsen et al.,1999). reported that increasing level of urea in diets of growing goats to $0.4 \%$ was resulted in decreasing $(p<0.05)$ NB as $\%$ of NI.Nitrogen balance obtained in this study were closed to that reported by (Yacout and El- Badawi 2001). They found that $\mathrm{N}$ balance of goats fed rations contained $12 \% \mathrm{CP}$ was $41.4 \mathrm{~g} / \mathrm{h} / \mathrm{d}$.

Table(5): Digestion coefficients and nutritive values of mixtures silages fed by experimental goats.

\begin{tabular}{|c|c|c|c|}
\hline Items & $\mathbf{R}_{\mathbf{3}}$ & $\mathbf{R}_{\mathbf{2}}$ & $\mathbf{R}_{1}$ \\
\hline \multicolumn{4}{|c|}{ Nutrients digestibility , \% } \\
\hline DM intake (kg /day ) & $1.958^{\mathrm{A}}$ & $1.824^{B}$ & $1.759^{\mathrm{B}}$ \\
\hline DM & $71.37^{\mathrm{B}}$ & $73.97^{A}$ & $73.62^{\mathrm{A}}$ \\
\hline OM & $69.54^{B}$ & $71.57^{\mathrm{A}}$ & $70.32^{A}$ \\
\hline $\mathrm{CP}$ & $71.59 \mathrm{~B}$ & $76.94^{A}$ & $74.11 \mathrm{~A}$ \\
\hline $\mathrm{CF}$ & $62.81^{\mathrm{B}}$ & $67.51^{\mathrm{A}}$ & $65.39^{A}$ \\
\hline $\mathrm{EE}$ & $70.49^{\mathrm{B}}$ & $75.22^{\mathrm{A}}$ & $74.97^{\mathrm{A}}$ \\
\hline NFE & $71.35^{\mathrm{B}}$ & $74.63^{A}$ & $73.15^{A}$ \\
\hline GE & $68.30^{B}$ & 71.60 & $70.30^{A}$ \\
\hline \multicolumn{4}{|c|}{ Fiber fractions , \% } \\
\hline NDF & $63.70^{\mathrm{B}}$ & $64.60^{A}$ & $68.40^{A}$ \\
\hline ADF & $61.20^{\mathrm{B}}$ & $63.80^{\mathrm{A}}$ & $64.30^{\mathrm{A}}$ \\
\hline ADL & $32.80^{\mathrm{B}}$ & $34.50^{\mathrm{A}}$ & $35.90^{\mathrm{A}}$ \\
\hline Hemicelluloses & $56.20^{\mathrm{B}}$ & $58.60^{\mathrm{B}}$ & $62.80^{A}$ \\
\hline Celluloses & $65.50^{\mathrm{B}}$ & $67.40^{\mathrm{A}}$ & $70.90^{A}$ \\
\hline NFC & $67.89^{\mathrm{B}}$ & $69.59^{A}$ & $68.19^{A}$ \\
\hline \multicolumn{4}{|c|}{ Nutritive values } \\
\hline TDN\% OF DM & 58.73 & 60.86 & 59.55 \\
\hline TDN kg / day & 12.82 & 12.45 & 11.91 \\
\hline TDN kg / kg milk & 8.71 & 7.70 & 7.43 \\
\hline NED Mcal/ kg & 1.53 & 1.55 & 1.54 \\
\hline NEL Mcal/ kg & 0.75 & 0.78 & 0.84 \\
\hline NEL / NED \% & 49.0 & 50.3 & 54.6 \\
\hline NFC/ DCP & 2.83 & 2.52 & 2.65 \\
\hline \multicolumn{4}{|c|}{ Energy concentration } \\
\hline $\mathrm{ME}$ & 2.367 & 2.449 & 2.467 \\
\hline GE & 4.373 & 4.489 & 4.526 \\
\hline $\mathrm{DE}$ & 2.887 & 2.986 & 3.009 \\
\hline $\mathrm{NE}$ & 1.572 & 1.613 & 1.596 \\
\hline \multicolumn{4}{|c|}{ Metabolisability \% } \\
\hline ME/GE & 54.12 & 54.56 & 54.51 \\
\hline \multicolumn{4}{|c|}{ Efficiency / ME utilization \% } \\
\hline RFQ & $233.01 \mathrm{~A}$ & $214.96^{\mathrm{B}}$ & $232.55^{\mathrm{A}}$ \\
\hline QI & 3.01 & 2.78 & 3.00 \\
\hline RFV & $167.70^{A}$ & $147.55^{c}$ & $153.33^{B}$ \\
\hline DDM & 44.33 & 42.87 & 42.36 \\
\hline NE/ME & 66.41 & 64.23 & 64.29 \\
\hline
\end{tabular}

$A$ and $B$ Means having different superscripts within the same row are significantly different at $(\mathrm{P}<0.05)$. 
Table ( 6 ): Nitrogen utilization of experimental rations by dairy Zaribi goats.

\begin{tabular}{|l|c|c|c|}
\hline \multirow{2}{*}{ Items } & \multicolumn{3}{|c|}{ Experimental rations } \\
\cline { 2 - 4 } & $\mathbf{R}_{\mathbf{1}}$ & $\mathbf{R}_{\mathbf{2}}$ & $\mathbf{R}_{\mathbf{3}}$ \\
\hline $\mathrm{N}$ intake $(\mathrm{g} / \mathrm{h} / \mathrm{d})$ & $46.13^{\mathrm{B}}$ & $44.36^{\mathrm{B}}$ & $48.9^{\mathrm{A}}$ \\
\hline Fecal $\mathrm{N}(\mathrm{g} / \mathrm{h} / \mathrm{d})$ & $11.46^{\mathrm{B}}$ & $11.6^{\mathrm{B}}$ & $12.4^{\mathrm{A}}$ \\
\hline Urinary $\mathrm{N}(\mathrm{g} / \mathrm{h} / \mathrm{d})$ & $15.48^{\mathrm{A}}$ & $13.58^{\mathrm{B}}$ & $14.81^{\mathrm{A}}$ \\
\hline $\mathrm{N}$ excretion $(\mathrm{FU}+\mathrm{UN})$ & $26.94^{\mathrm{B}}$ & $25.34^{\mathrm{B}}$ & $27.5^{\mathrm{A}}$ \\
\hline Digestion $\mathrm{N}(\mathrm{g} / \mathrm{h} / \mathrm{d})$ & $32.67^{\mathrm{B}}$ & $33.60^{\mathrm{B}}$ & $34.4^{\mathrm{A}}$ \\
\hline $\mathrm{N}-$ balance $(\mathrm{g} / \mathrm{h} / \mathrm{d})$ & $19.19^{\mathrm{B}}$ & $21.02 \mathrm{~B}$ & $20.64^{\mathrm{A}}$ \\
\hline $\mathrm{NB} / \mathrm{NI}, \%$ & $41.59^{\mathrm{A}}$ & $42.87^{\mathrm{B}}$ & $42.65^{\mathrm{A}}$ \\
\hline
\end{tabular}

$A$ and $B$ Means having different superscripts within the same row are significantly different at $(P<0.05)$.

\section{Milk production and composition}

Milk yeild of dairy Zabibi goats as affected by feeding experimental rations are presented in Table (7).Data obtained showed that there differences $(p<0.05)$ in milk yield among experimental rations. These results may be attributed to the increase of nutritive values of $\mathrm{R}_{2}$ and $\mathrm{R}_{3}$ rations. The current results are in accordance with those reported by (Kholif et al.,1999) and (El-Ashry et al.,2001),they found that milk yield was ranged between $(2.0-2.1 \mathrm{~kg} /$ head /day)for lactating goats and $6.1-8.6 \mathrm{~kg} / \mathrm{head} /$ day)for lactating buffaloes fed ration contained $50 \%$ concentrate and $50 \%$ roughage. On the other side the milk constituents indicated that second and third groups were significantly $(p<0.05)$ higher of all milk constituents compared to control group.The changes in milk contents may be due to the level of prolactin hormone secretion and efficiency of udder secretary cells.(Soliman et al., 1995)..Total solid \%,solid non fat \% and lactose $\%$ were significantly $(p<0.05)$ increased when feeding $\mathrm{R}_{2}$ or $\mathrm{R}_{3}$ rations compared to $\mathrm{R}_{1}$. These results are agreed with the results reported by (Allam et al.,2001)and (El-Ashry et al.,2001).The percentage of milk protein $\%$ and fat $\%$ were lower $(p<0.05)$ with feeding on $R_{1}$ and $R_{3}$ rations than $R_{2}$,while there was no significant differences between $R_{1}$ and $R_{3}$.Increasing fat\% synchronized with Ray grass and Rod grass mixtures silage in goats rations may be due to higher fermentation of fiber into volatile fatty acid in rumen Table(9).It had subsequently converted to fat in milk,that agreed with (Jin et al. 2007).On the other hand protein and lactose content increased in similar trend, this may be due to DCP and TDN intake Table (5). These results agreed with those obtained by (Ahmed et al. 2003) and Bendary et al. 2000). The whey protein nitrogen (WPN\%), whey protein(WP\%)and acidity recorded higher values with significant $(p<0.05)$ increase when feeding with $R_{2}$ and $R_{3}$ in comparison with R1 group . Furthermore the milk composition as well as, protein yield, solids yield, fat yield, solid not fat yield, lactose yield ash were recorded significantly lower values $(p<0.05)$ for $\mathrm{R} 1$ ration than others. However, the NE $\mathrm{Mcal} / \mathrm{kg}$ no differences were observed among experimental treatments 
Table(7):Effect of mixture silage on milk yield and composition of lactating Zaribi goats.

\begin{tabular}{|c|c|c|c|}
\hline Items & $\mathbf{R}_{\mathbf{3}}$ & $\mathbf{R}_{\mathbf{2}}$ & $\mathbf{R}_{1}$ \\
\hline Total milk yield , kg / h/ period & $176.52^{\mathrm{B}}$ & $198.36^{\mathrm{A}}$ & $194.16^{\mathrm{A}}$ \\
\hline Daily milk yield (kg/h/d) & $1.471^{\mathrm{B}}$ & $1.603^{\mathrm{A}}$ & $1.618^{\mathrm{A}}$ \\
\hline Protein \% & $3.79 \mathrm{~B}$ & $4.08^{\mathrm{A}}$ & $3.97^{\mathrm{B}}$ \\
\hline Total solid\% & $14.23^{\mathrm{B}}$ & $15.71 \mathrm{~A}$ & $15.56^{\mathrm{A}}$ \\
\hline Fat $\%$ & $3.90^{\mathrm{B}}$ & $4.10^{\mathrm{A}}$ & $3.98^{\mathrm{B}}$ \\
\hline Total N ( TN ) & 0.60 & 0.65 & 0.64 \\
\hline Solid not fat( SNF\%) & $10.33^{\mathrm{B}}$ & $11.71^{\mathrm{A}}$ & $11.5^{\mathrm{A}}$ \\
\hline Lactose $\%$ & $4.60^{\mathrm{B}}$ & $5.10^{\mathrm{A}}$ & $5.00^{\mathrm{A}}$ \\
\hline Non casein nitrogen (NCN\%) & 0.17 & 0.18 & 0.20 \\
\hline Non protein nitrogen ( NPN \%) & 0.04 & 0.6 & 0.7 \\
\hline Casein nitrogen ( $\mathrm{CN} \%)$ & 0.43 & 0.44 & 0.46 \\
\hline Casein \% & 2.75 & 2.81 & 2.94 \\
\hline Whey protein nitrogen( WPN\%) & $0.11^{\mathrm{B}}$ & $0.12^{\mathrm{A}}$ & $0.13^{\mathrm{A}}$ \\
\hline Whey protein ( WP\%) & $71.00^{\mathrm{B}}$ & $77.00^{\mathrm{A}}$ & $83.10^{\mathrm{A}}$ \\
\hline \multicolumn{4}{|c|}{ Milk constituents yield gm / h/day } \\
\hline protein yield gm / h/day & $55.76^{\mathrm{B}}$ & $65.40^{\mathrm{A}}$ & $64.24^{\mathrm{A}}$ \\
\hline solids yield gm / h/day & $209.32^{\mathrm{B}}$ & $251.80^{\mathrm{A}}$ & $251.76^{A}$ \\
\hline fat yield gm / h/day & $57.37^{\mathrm{B}}$ & $64.12^{\mathrm{A}}$ & $64.40^{\mathrm{A}}$ \\
\hline Solid not fat yield gm / h/day & $151.9^{\mathrm{B}}$ & $182.90^{\mathrm{A}}$ & $187.36^{\mathrm{A}}$ \\
\hline Lactose yield gm / h/day & $67.67^{\mathrm{B}}$ & $81.75^{\mathrm{A}}$ & $80.90^{\mathrm{A}}$ \\
\hline Ash\% & $0.784^{B}$ & $0.839 \mathrm{~A}$ & $0.816^{\mathrm{A}}$ \\
\hline Acidity \% & $0.189^{A}$ & $0.176^{\mathrm{B}}$ & $0.172^{\mathrm{B}}$ \\
\hline NE ( Mcal / kg) & 0.748 & 0.750 & 0.785 \\
\hline
\end{tabular}

\section{Blood profile}

Values of some blood parameters are presented in(Table 8)Data obtained of $R_{1}$ group explained that there were decrease significant differences for free fatty acids (FFA), total lipids, triglycerides, cholesterol, Total lipids, Trigly-cerides, urea- $\mathrm{N}$ and Glucose compared to $\mathrm{R}_{2}$ and $\mathrm{R}_{3}$ groups, the higher value of serum urea-N of $R_{2}$ and $R_{3}$ may be due to higher level of ammonia- $\mathrm{N}$ in the rumen as reported also by lbrahim et al. (2008).on the other hand ,haematocrit(HC),Bilirubin, Alk-P-ase and WBCs for $\mathrm{R}_{2}$ and $\mathrm{R}_{3}$ were recorded lower significant differences than $R_{1}$ group.In addition to the higher blood lipids might be due to the inhibition in lipiogenic enzyme activities by liver and adipose tissue of animals fed rations containing fat Storry (1981).Thus the blood minerals as well as calcium, phosphorus and magnesium in $\mathrm{R}_{2}$ ration was recorded higher values than those obtained with $R_{1}$ and $R_{3}$ groups. This may indicate that nutrients were more available and utilizable,this results are agreed with those reported by Steele(1980).On the other hand hematological picture of goats fed experimental rations showed that there significant $(p<0.05)$ decreased in erythrocyte and leucocytes for $R_{2}$ and $R_{3}$ groups compared to $R_{1}$. In addition to the fractions of white blood cells (lymphocyte, Neutrophile and Eiosinophile\%) were significantly increased with $R_{1}$ group, whereas monocyte was decrease for same group than the other experimental groups. This increases of lymphocyte,neutrophile and Eiosinophile in $R_{1}$ group may be due back to the increases of saponine level because saponine have an enhancement effect to the humoral immune response and increase white blood cells as reported by Saleh et al . ( 2007 ). 
Table(8):Blood plasma constituents and some minerals of dairy Zaribi goats as affected by experimental rations fed by.

\begin{tabular}{|c|c|c|c|}
\hline \multirow[t]{2}{*}{ Items } & \multicolumn{3}{|c|}{ Experimental rations } \\
\hline & $\mathbf{R}_{\mathbf{3}}$ & $\mathbf{R}_{\mathbf{2}}$ & $\mathbf{R}_{1}$ \\
\hline Haematocrit values ( \% ) & $18.36^{\mathrm{A}}$ & $15.76^{\mathrm{B}}$ & $16.97^{\mathrm{B}}$ \\
\hline Total protein $(\mathrm{gm} / \mathrm{dl})$ & 7.34 & 7.83 & 7.64 \\
\hline Albumen ( gm / dl ) & 4.86 & 4.28 & 4.71 \\
\hline Globulin (gm / dl) & 2.48 & 3.55 & 2.93 \\
\hline Glucose, mg/dl & $76.34^{\mathrm{B}}$ & $81,48^{\mathrm{A}}$ & $78.2^{\mathrm{A}}$ \\
\hline Urea-N, mg/dl & $17.45^{\mathrm{B}}$ & $19.87^{\mathrm{A}}$ & $19.27^{\mathrm{A}}$ \\
\hline FFA ( $\mathrm{m} . \mathrm{mol} / \mathrm{L})$ & $389.23^{\mathrm{B}}$ & $416.78^{\mathrm{A}}$ & $399.69^{A}$ \\
\hline Total lipids ( $\mathrm{g} / \mathrm{dL}$ ) & $7.34^{\mathrm{B}}$ & $9.21^{\mathrm{A}}$ & $9.59^{\mathrm{A}}$ \\
\hline Triglycerides $(\mathrm{mg} / \mathrm{dL})$ & $78.93^{\mathrm{B}}$ & $94.65^{\mathrm{A}}$ & $88.12^{\mathrm{A}}$ \\
\hline Cholesterol ( $\mathrm{mg} / \mathrm{dl})$ & $62.48^{\mathrm{B}}$ & $78.94^{\mathrm{A}}$ & $78.36^{A}$ \\
\hline Bilirubin $(\mathrm{mg} / 100 \mathrm{ml})$ & $0.42^{\mathrm{A}}$ & $0.187^{\mathrm{B}}$ & $0.197^{\mathrm{B}}$ \\
\hline Alk-P-ase( lu / L ) & $56.4^{\mathrm{A}}$ & $16.79^{\mathrm{B}}$ & $18.34^{\mathrm{B}}$ \\
\hline $\mathrm{Ca}(\mathrm{mg} / \mathrm{dL})$ & 10.26 & 11.94 & 10.68 \\
\hline$P(\mathrm{mg} / \mathrm{dL})$ & 6.14 & 6.70 & 6.33 \\
\hline $\mathrm{Mg}(\mathrm{mg} / \mathrm{dL})$ & $8.53^{\mathrm{B}}$ & $10.34^{\mathrm{A}}$ & $8.28^{\mathrm{B}}$ \\
\hline WBCs $\left(10^{3} \mathrm{ul}\right)$ & $7.43^{\mathrm{A}}$ & $6.20^{\mathrm{B}}$ & $6.10^{\mathrm{B}}$ \\
\hline Lymphocyte (\%) & $63.7^{\mathrm{A}}$ & $57.37^{\mathrm{B}}$ & $55.87^{\mathrm{B}}$ \\
\hline Neutrophile ( \%) & $57.9^{\mathrm{A}}$ & $41.87^{\mathrm{B}}$ & $42.57^{\mathrm{B}}$ \\
\hline Eiosinophile ( \% ) & $6.9^{A}$ & $4.7^{\mathrm{B}}$ & $5.27^{\mathrm{B}}$ \\
\hline Monocyte (\% ) & $14.77^{\mathrm{B}}$ & $21.90^{\mathrm{A}}$ & $17.57^{\mathrm{B}}$ \\
\hline
\end{tabular}

$A$ and $B$ Means having different superscripts within the same row are significantly different at $(P<0.05)$.

\section{Ruminal fermentation parameters}

Table (9) presented the criteria obtained from ruminal tested fluid fermentation parameters of lactating Zaribi goats under investigation.The ruminal $\mathrm{pH}$ values and the maximum total VFA's values were recorded at 3 hrs post feeding.The same trend was obtained by(Johnson and Sultan1968),(Allam et al.1984).Moreover,ruminal ammonia-N concentrate were greatly higher and the maximum values were reached at 3 hrs postfeeding then decreased with all dietary treatments.Similar results were reported by (Ziad et al. 2009).subsequent, effective neutral detergent fiber (eNDF) was calculated to estimate adjustment of ruminal $\mathrm{pH}$ useful only when eNDF below $30 \%$.In addition to predication of ruminal $\mathrm{pH}$ and eNDF were used to adjust passage rate, Fouad (2002).

Table ( 9 ):The effect of experimental rations on some rumen liquor Parameters of lactating Zaribi goats.

\begin{tabular}{|l|c|c|c|c|c|}
\hline \multicolumn{1}{|c|}{ Items } & Time & $\mathbf{R}_{\mathbf{1}}$ & $\mathbf{R}_{\mathbf{2}}$ & $\mathbf{R}_{\mathbf{3}}$ & SIM \\
\hline \multirow{4}{*}{$\mathrm{PH}$ - values } & 0 & 6.84 & 6.94 & 6.76 & 0.21 \\
\hline \multirow{3}{*}{ NH3(mg/100ml RL) } & 3 & 6.35 & 6.58 & 6.41 & 0.15 \\
\cline { 2 - 6 } & 6 & 6.61 & 6.83 & 6.73 & 0.11 \\
\hline \multirow{3}{*}{ TVF's(mequ./100ml RL) } & 0 & $16.48^{\mathrm{B}}$ & $18.37^{\mathrm{A}}$ & $19.45^{\mathrm{A}}$ & 0.31 \\
\cline { 2 - 6 } & 3 & $22.76^{\mathrm{B}}$ & $25.83^{\mathrm{A}}$ & $26.87^{\mathrm{A}}$ & 0.09 \\
\cline { 2 - 6 } & 6 & $18.55^{\mathrm{B}}$ & $20.52^{\mathrm{B}}$ & $23.14^{\mathrm{A}}$ & 0.14 \\
\hline \multirow{3}{*}{$\%$ eNDF* } & 0 & $12.61^{\mathrm{A}}$ & $14.67^{\mathrm{B}}$ & $15.36^{\mathrm{B}}$ & 0.19 \\
\cline { 2 - 6 } & 3 & $15.29^{\mathrm{B}}$ & $17.88^{\mathrm{B}}$ & $19.49^{\mathrm{A}}$ & 0.13 \\
\cline { 2 - 6 } & 6 & $14.71^{\mathrm{B}}$ & $16.23^{\mathrm{B}}$ & $18.55^{\mathrm{A}}$ & 0.22 \\
\cline { 2 - 6 } & 3 & $33.46^{\mathrm{A}}$ & $35.82^{\mathrm{A}}$ & $31.57^{\mathrm{B}}$ & 0.78 \\
\cline { 2 - 6 } & 6 & $21.87^{\mathrm{B}}$ & $27.31^{\mathrm{A}}$ & $23.29^{\mathrm{B}}$ & 0.49 \\
\cline { 2 - 6 } & $28.02^{\mathrm{B}}$ & $33.22^{\mathrm{A}}$ & $30.86^{\mathrm{B}}$ & 0.82 \\
\hline
\end{tabular}

$A$ and $B$ Means having different superscripts within the same row are significantly different at $(P<0.05)$. * effective neutral detergent fiber $(\mathrm{eNDF})=(\mathrm{pH}-5,425) / 0.04229 \quad$ ( Fox et al . 2000) 
Molar proportion of ruminal volatile fatty acid (VFA's)

Data in Table (10) illustrated that there were differences between acetic, propionate , butrtate and Iso-biotrate values of rumen liquor of goats fed experimental rations. Acetic, butrtate and iso-biotrate of $R_{2}$ ration were significant $(p<0.05)$ decrease compared to $R_{1}$ and $R_{3}$ rations.Whereas propionate and valerate were recorded higher values with $R_{2}$ group.This results were agreed with those represented by (Mohammed et al.,2003). Ruminal ammonia-N concentration was greatly higher at 3 and 6 hrs postfeeding than before-feeding. The same trend was observed by Ibrahim et al. (2012).The lowest values of ruminal ammonia- $N$ were recorded with $R_{1}$ and the highest values were detected with $R_{2}$ and $R_{3}$ and the differences were significant at 3 and 6 hrs post-feeding only. This increase in ruminal ammonia$\mathrm{N}$ concentration in $\mathrm{R}_{2}$ and $\mathrm{R}_{3}$ may be due to the high content of $\mathrm{CP}$ in rations as reported earlier in Table1. The same results were observed by Ahmed et al.( 2013) with using berseem silage and its mixtures with some grasses in goats rations. The average concentrations of total VFA's post-feeding ( 3 and 6 $h r s$ ) in the rumen were significantly decreased with $R_{1}$ compared with $R_{2}$ and $R_{3}$. Similar findings were shown by Haggag et al. (2002).and El-Kholany (2004) using mixture forage and silage in Rahmani sheep and Zaraibi goats.

Table (10). Mollar proportion of ruminal volatile fatty acid ( VFAs) of dairy Zaribi goats fed on experimental rations .

\begin{tabular}{|l|c|c|c|}
\hline Item & $\mathbf{R}_{\mathbf{1}}$ & $\mathbf{R}_{\mathbf{2}}$ & $\mathbf{R}_{\mathbf{3}}$ \\
\hline Acetate $\%$ & $38.09^{\mathrm{A}}$ & $33.47^{\mathrm{B}}$ & $36.61^{\mathrm{A}}$ \\
\hline Propionate $\%$ & $27.84^{\mathrm{B}}$ & $34.51^{\mathrm{A}}$ & $28.85^{\mathrm{B}}$ \\
\hline $\mathrm{A}: \mathrm{p}$ & $1.43: 1$ & $1.03: 1$ & $1.63: 1$ \\
\hline Butrtate, \% & $21.57^{\mathrm{A}}$ & $17.2^{\mathrm{B}}$ & $19.84^{\mathrm{A}}$ \\
\hline Iso - biotrate \% & $2.68^{\mathrm{A}}$ & $1.67^{\mathrm{B}}$ & $2.91^{\mathrm{A}}$ \\
\hline \multicolumn{2}{|l|}{ Valerate, \% } & $2.49^{\mathrm{A}}$ & $1.37^{\mathrm{B}}$ \\
\hline
\end{tabular}

\section{Total bacterial count of rumen liquor}

The obtained results of total viable bacteria count for $R_{2}$ ration was recorded higher significant than $R_{1}$ and $R_{3} R_{3}$. Table (11)illustrates the data collected for microbial protein of goats under investigation.Ruminal microbial protein was significantly different among three treatments at zero time and was significantly $(P<0.05)$ higher with $R_{2}$ than of $R_{1}$ at 3 and 6 hrs postfeeding. But, $R_{3}$ recorded the medium values. This positive effect of mixture silage on ruminal microbial protein was observed also by Shehata et al. (2001), in the rumen of bucks, lambs and lactating does, respectively. The results obtained from this study are in harmony with those of (Kurihara et al.1968) who observed that the peak of bacterial counts was between 3 and 6 hr's after feedi .Nour et al.(1989),reported that the active bacterial population in the rumen may help to increase the rate of digestion.Total cellulolytic bacterial count of rumen liquor recorded the highest values at $3 \mathrm{hrs}$ after feeding within $R_{2}$ but the lowest value was in $R_{1}$ and $R_{3}$ groups.

Total protozoal count of rumen liquor after $3 \mathrm{hrs}$ of feeding showed the lowest value with $R_{1}$ compared to the other tested rations, and the highest value was obtained with $R_{2}$ group. Perhaps that back to lower level of 
Saponine in $\mathrm{R}_{2}$ ration ,this result agreement with those obtained by Sony and Sharma(1982), who found significantly increased in ciliate protozoal count with. increasing concentrate level in diet.This possibly related to ingest starch. Maximum protozoal counts were observed at $3 \mathrm{hrs}$ post feeding than after 6 hrs post feeding

Table (11). Effect of experimental rations on rumen microorganisms

\begin{tabular}{|l|c|c|c|c|}
\hline Items & Time & $\mathbf{R}_{\mathbf{1}}$ & $\mathbf{R}_{\mathbf{2}}$ & $\mathbf{R}_{\mathbf{3}}$ \\
\hline Total bacterial count $\left(10^{7} / \mathrm{ml}\right)$ & 0 & $1519^{\mathrm{B}}$ & $1860^{\mathrm{A}}$ & $1347^{\mathrm{C}}$ \\
\hline Cellullolytic bacterial $\left(10^{4} / \mathrm{ml}\right)$ & 3 & $2175^{\mathrm{B}}$ & $2617^{\mathrm{A}}$ & $2080^{\mathrm{C}}$ \\
\cline { 2 - 5 } & 6 & $3818^{\mathrm{B}}$ & $4346^{\mathrm{A}}$ & $3576^{\mathrm{C}}$ \\
\hline \multirow{2}{*}{ Total protozoal count $\left(10^{4} / \mathrm{ml}\right.$} & 0 & $2.91^{\mathrm{B}}$ & $3.16^{\mathrm{A}}$ & $2.46^{\mathrm{B}}$ \\
\hline & 3 & $4.68^{\mathrm{A}}$ & $5.57^{\mathrm{A}}$ & $3.91^{\mathrm{B}}$ \\
\cline { 2 - 5 } & 6 & $3.72^{\mathrm{B}}$ & $4.65^{\mathrm{A}}$ & $2.64^{\mathrm{C}}$ \\
\hline
\end{tabular}

$A, B$ and $C$ Means having different superscripts within the same row are significantly different at $(P<0.05)$.

\section{Growth performance of born kids}

Table(12)showed the variations in body weight gain of kids whose sucking their dams milk, the results were recorded high significant BWG with $R_{2}$ followed by $R_{3}$ compared to those in $R_{1}$ group.This increase of daily weight gain may be back to the higher milk yield and its content of total solid, total protein and milk fat(Table7).Thereby, the feed conversion was lower values with $R_{2}$ and $R_{3}$ than $R_{1}$ and the values were $6.00,5.36$ and 5.64 for $\mathrm{R}_{1}, \mathrm{R}_{2}, \mathrm{R}_{3}$ respectively.

Table ( 12 ) : Growth performance of born kids as affected by the tested rations .

\begin{tabular}{|l|c|c|c|}
\hline Items & $\mathbf{R}_{\mathbf{1}}$ & $\mathbf{R}_{\mathbf{2}}$ & $\mathbf{R}_{\mathbf{3}}$ \\
\hline Initial weight $(\mathrm{kg} \mathrm{)}$ & 3.55 & 3.45 & 3.70 \\
\hline Weaning weight $(\mathrm{kg} \mathrm{)}$ & 23.71 & 24.95 & 24.75 \\
\hline Total body gain $(\mathrm{kg} \mathrm{)}$ & 20.16 & 21.50 & 21.05 \\
\hline Daily gain $(\mathrm{g})$ & 168.00 & 179.17 & 175.42 \\
\hline Milk consumption $(\mathrm{kg} / \mathrm{h} / \mathrm{d})$ & $1.01^{\mathrm{A}}$ & $0.96^{\mathrm{B}}$ & $0.99^{\mathrm{A}}$ \\
\hline Feed conversion & $6.00^{\mathrm{A}}$ & $5.36^{\mathrm{B}}$ & $5.64^{\mathrm{A}}$ \\
\hline
\end{tabular}

$A$ and $B$ Means having different superscripts within the same row are significantly different at $(P<0.05)$.

\section{Economical efficiency}

Calculated economic efficiency are presented in Table(13).It based upon milk production of does,BWG of kids and total intake costs.Subsequent, final body weight and feeding cost are the most important factor affecting the maximum efficiency of milk yield and meat production. Ragrass 140 L.E./ton and Rod grass 140 L.E. where $\mathrm{kg}$ milk was $3 \mathrm{~L}$.E., while selling price of $1 \mathrm{~kg}$ of live live weight was 25 L.E.according to local prices of year $2013[\$=6.75$ L.E.(Egyptian Pound)].The results illustrated that when goats fed ration The price of concentrate feed mixture / ton was 2500 L.E./ ton, berseem hay 1000 L.E./ ton Net revenue $=\{($ Selling income of milk + Selling income of BWG)-coast of feed intake (LE) $\}$

Economic efficiency \% = Net revenue / animal (LE)

Total feed Coast (LE))
containing forages mixtures silage with high level of mitabolizable energy (ME), the cost / kg BW was decreased, specially with $R_{1}$ and $R_{3}$. The corresponding values of the economical efficiency were increased 23.00 and $19.00 \%$ for $R_{2}$ and $R_{3}$ respectively than those of control group. This indicated 
that the replacement of $50 \%$ of total Egyptian berseem by $\operatorname{Ray}\left(R_{2}\right)$ and Rodgrass $\left(R_{3}\right)$ in goats feeding give higher net revenue and economic efficiency values compared to control group $\left(R_{1}\right)$. This improvement in economic efficiency could be attributed to improvement in both growth rate and feed conversion ratio. Whereas no significant different was observed between $R_{2}$ and $R_{3}$ groups.this results were in agreement with those obtained by (Murdoch ,1962).

Table(13):Economical efficiency(LE)of tested rations on growth of born kids .

\begin{tabular}{|c|c|c|c|}
\hline Items & $\mathbf{R}_{1}$ & $\mathbf{R}_{\mathbf{2}}$ & $\mathbf{R}_{\mathbf{3}}$ \\
\hline \multicolumn{4}{|c|}{ Feed intake $\mathrm{kg} / \mathrm{h}$} \\
\hline DM intake $(\mathrm{kg} / \mathrm{h})$ & $2495^{A}$ & $2390^{B}$ & $2360^{B}$ \\
\hline DM intake ( $\mathrm{kg}$ over all )period & 299.4 & 286.8 & 283.2 \\
\hline Coast of intake ( LE ) & 555.00 & 477.60 & 478.95 \\
\hline \multicolumn{4}{|c|}{ Milk consumption, Total milk yield and Price of milk / $\mathrm{h}$ overall (LE) } \\
\hline Milk consumption(gm/h/d) & $1953^{A}$ & $1780^{\mathrm{B}}$ & $1918^{A}$ \\
\hline Total milk yield ( LE ) & 224.52 & 234.36 & 230.16 \\
\hline Price of milk/h overall(LE) & 673.56 & 703.08 & 690.48 \\
\hline \multicolumn{4}{|c|}{ Body weight gain of offspring (kg) } \\
\hline Total body weight gain $(\mathrm{kg})$ & 20.16 & 21.50 & 21.05 \\
\hline Price of BG (LE) & 504.00 & 537.50 & 526.25 \\
\hline \multicolumn{4}{|c|}{ Revenue(LE) } \\
\hline Net revenue / animal (LE) & 622.56 & 762.98 & 737.73 \\
\hline Economical efficiency \% & $100.00^{\mathrm{B}}$ & $123.00^{\mathrm{A}}$ & $119.00^{\mathrm{A}}$ \\
\hline
\end{tabular}

\section{CONCLUSION}

In conclusion, using $60 \%$ of forage mixtures silages as Egyptian berseem silage (EBS), EBS $\times$ Ray grass or EBS $\times$ Rod grass)are suitable for dairy Zaribi goats feeding compared to EBS alone .These silage mixtures improved milk production and performance of born kids received their mothers milk ,and decreased feeding cost .On the other side the decreased of Ray and Rodgrass silage prices had adverse effects on animal production, which was reflected on feeding cost and economical Efficiency .

\section{REFFERENCES}

Abdelhamid,A.M.; M.S.Nowar;S.M.Bassuny and G.I.El-Emam (2001).Evalution of unconventional silage making using plant and animal wastes in feeding ruminants. J. Agric.Sci.Mansoura Univ.,26 : 5349 - 5360.

Abou Akkada,A.R.(1984).Evaluation of present status and potential develop -ment of animal feed resources in the Arab countries khartom,p129.

Abou Akkada,A R.and A.M.Nour,(1986).Ensilage and improvement of feeding value Proceeding of Conference of Animal Production, In the 26th Century,16-18 Septamber, Alexandria, p.40.

Aboul Ella,A.A.(2000).Mathematical programing models applied to feed formul ation for ruminants .Ph.D.Thesis in animal Nutrition,Faculty of Agrriculture,Ain-Shms, University ,Shubra El-Khe, Cairo Egypt.

Ahmed,B.M.; H.T.Taie;M.M.Bendary and K.F.Abdel-Latif (2003).Influence of dietary corn silage on digestibility performance and economical efficiency of dietary cattle.Egyptian Journal Nutrition and Feeds, 6 (Special issue):587-594. 
Allam,A.M.;A.K.Abou-Raya;E.A.Gihad and T.M.El-Bedawy(1984).Nutritional studies by sheep and goats fed $\mathrm{NaOH}$ treated straw.1st Egyptian British Conf. Anim.And Poultry Prod.,Zagazig Univ.,11-13Sep.,p.53.

Allam , A.M.; K.El-Shazly ; B.E.A.Borhami and M.A.Mohmed (2001).Effect of Bakers yeast Saccharomyces cervisia supplementation on diges -ion in Sheep.Proc.of the 8 th Conf.on Anim.Nutrition .Sharm,

El-Shikh, Egypt , 23-26 October 2001. Egtptian J. Nutrition and Feeds,4 ( Specil issue): 315.

Al-Yousef,Y.M.;F.N.AIMulhim;G.A.El- Hag and G.A.Al-Gsim,(1994).utilization of diets with different forage mixtures with Egyptian berseem by growing awassi lambs.Annals.Agric.,Sci.Ain Shams Univ.,39(2), 663-670.

A.O.A.C.(2000).Association of Official Analytical Chemists.Official Methods of Analysis17ed.Washington D.C.

Auldist, D.E.; K.L. Atkinson; M. J. Silvapulle ;D.W.Dellow, and G.H. McDowell(1999).Utilization of white clover silage fed alone or with maize silage by lactating dairy cows.Austr.J.Exp.Agric.39:237-246.

Authi , K.S.; Rao ,G.H.R.; B.J. Evenden and N.Crawford (1988) Action of Guanosine 50-(beta-thio) diphosphate on thrombin-induced activation and calcium mobilization in saponin-permeabilized and intact human platelets. Biochemical Journal 255, $885-894$.

Bartiles, H .(1971).Colorimetric determination of creatinine.Clin. Acta,32-81.

Bendary, M.M.;S.A.El-Ayouty;F.H.H.Farrage;A.M.A .Mohiel - Din and F.M. KhalilF,(2000).Productive performance of lactating cows fed rations containing different forms of sugar beet tops and berseem silage.Proceeding of Conference of Animal Production, In the 21th Century,18-20 April, Sakha, Egypt, Pp. 255-265.

Castle,M.E.;D.Reid and J.N.Watson.(1983).Silage and milk production:studies with diets containing white clover silage.Grass For.Sci.38:193-200.

Choi,S.; S.Y.Jung ;C.H.Kim.; HS.Kim; H.Rhim ; S.C.Kim and S,Y,Nah(2001) Effect of ginsenosides on voltage dependent Ca2+subtypes Chann el in bovine chromaffin cells.Journal of Ethnopharmacology. 74,75-81.

Conway,E.J.(1962).Microdefusion Analysis and Volumatric Error( $\left.5^{\text {th }} \mathrm{Ed}\right)$ Crosby-Lock wood and Sons LK td .London .

Doumas, B.T.; W.Watson and H.G.Biggs,(1971). A method of determination of plasma albumin. Cli. Chemists Acya, 31:87.

Duncan , D.B.(1955) .Multiple range and multiple F-test .Biometrics, 11:1-42 .

El-Ashry,M.A.;A.M.Kholif,H.A.;H.El-Amry;H.M.El-Sayed and T.A.El-Hamamsy (2001).Effect of different yeast cultures supplementation to diet on the productive performance of lactating buffaloes.Egyptian J.Nutr. And Feeds 4-21.

El Izzi , A.S.; T.N.Benie; M.L.Thieulant;L.Oliver anJ.Duval(1992).Stimulation of $\mathrm{LH}$ release from cultured pituitary cells by saponins of Petersia- nthus macrocarpus: a permeabilising effect.Planta Medica 58,229- 233.

El-Kholany, M. M (2004). Evaluation of some new green fodder for Farm animals. Ph.D. Thesis Fac. of Agric, Mansoura Univ.

Elveback ,L. R. ( 1970 ) Calcium determination in foods and feeds. J. Am. Med. Ass., 211: 69 . 
Fouad ,R.T.(2000).Effect of replacing corn by barely grain in concentrate feed mixture on the performance of sheep.J.Agric Scie . Mansoura Univ. , 27 ( 3 ): 1371-1380.

Haggag, M. El-H., E. S. Soliman and M.E. Ahmed (2002). Triticale forage as a feed for sheep. Proc., $1^{\text {st }}$ Ann. Sc. Conf. Anim. and Fish Prod, P. 77- 83. Mansoura, Sep,.

Hall, M.B.(2001). How should we formulate for non-NDF carbohydrate in:12 th annual Florida ruminant nutrition symposium . Gainsville, Fl. 44.

Goering , H.K.and P.J.Van Soest (1970).Forage fiber Analysis. A gric. Handbook, No . 379, USDA. Washington, DC. USA.

Hoffman, P.C.;D.K.Combs and M. D. Casler(1998).Performance of lactating dairy cows fed alfalfa silage or perennial ryegrass silage.J.Dairy Sci.81:162-168.

Ibrahim, F.A., E.S, Soliman, A. A. Abd El-Hamid and M. E. Ahmed. (2012). Growth performance and feed utilization efficiency of Rahmani lambs fed some legume and /or grass silages. Egyptian J. of Sheep and Goats Sciences, 7 (2): 1- 10.

Jin , G.L.;S.K. Choi;S.H.Choi;M.K.Song(2007).Effect of microbial additives on metabolic characteristics in sheep and milking performance of lactating dairy cows . Jurnal of Animal Science and Technology Center, Seoul Korea Republic :2007.49:779-828 .

Johnson ,V.W. and J.D.Sultan(1968). The continuous recordingof the $\mathrm{pH}$ in The small ruminant's .Br. J. Nutr. , 22: 303.

Kholif ,M.;M.M.Yossef ; H.El-Amary and S.A.H.Abo El-nor(1999).Productive and reproduction performance of lactating goats fed diets supplemented with different levels of dolomite .Proc.of the $7^{\text {th }}$ scientific conference on Animal Nutrition(19-21Oct.)2:97.El- Arish, Egypt.

Kurihara,Y.J.M.Eadie;P.N.Hobson andS.O.Mann (1968). Relationship between bacteria and cillate protozoa in sheep rumen.j.Gen.Microbial,51: 267-278.

Leupp,J.L.(2008).Use of corn distiller dried grains in beef cattele diets. Ph.D. Thisis,Fac. Of the North Dakota state Univerisity of agriculture and applied Science.

Ling , E.R.(1963 ).Text Book of Dairy Chemistry, Vol .11.Practical Champ Man and Hill, London . 3 rd Ed .

Linne , J.J. and K.M.Ringsrud (1992 ).Basic .Techniques in clinical Laboratory Science . 3 rd Ed., Mosby year book .

Menin,L;M.Panchichkina ;C.Keriel; J.Olivares; U.Braun;E.K.Seppert and V.A. Saks (2001).Macro compartmentation of total creatine Cardiomyocytes revisited.Molecular and Cellular Biochemistry 220,149-159.

Mohammad , M.I.;Y.A.A.Marrek and I.M.Awadalla (2003).Feed utilization and growth of dairy goats offered green forages silage as an alternative for berseem .J.Agric. Sci. Mansoura Univ.,28: 205-218.

Mohsen ,M.K.; M.F.Ali and M.I. Bassiouni (1999).The effect of partial replacing concentration mixture by ray and rod grass on perfrormanceof growing Angora goats. Proceeding of the 7 th . Scientific Confernce of Animal Nutrition 19-21 October, pp,309. El- Arish , Egypt . 
Monnet, L. ( 1963 ) . Determined of bilirubin . Animal Biol . Clin ., $21: 717$. Murdoch,J.(1962).Making and feeding silage.Farming Prees Books, LTD , London.

Murdoch,J.(962).Making and feeding silage.Farming Prees Books, LTD,London. Nour,A.M.;A.E.Tag El-Den;S.M.Z. Zahran and M.H.Ahmed(1989).Effect of feeding Agro-industrial by-products on total and differential proto- zoal counts in the rumen.Third Egyptian-British Conference on Animals Products.Alexandria,7-10 October,91-101.

NRC (1981).Nutrient Requirements of Domestic Animals. Nutrient Requirements of Goats. National Research Council, Washington,D.C.USA of Official Analytical Chemists, Washington, D.C.,USA .

Oleszek,W.A.(2002).Chromatographic determination of plant Saponins,J.of pharmacy and Pharmacology,vol.53,No.12,1Decemb 2002,PP.1637-1643 (7).

Patil, B.C.; R.P.Sharma ; D.K. Salunke and K.Salunkhe (1972).Evaluation of saponine as anti nutritional factor .Food . Cosmet.Toxicol.,10:, Toxicol., 10:395-398.

Patton ,C.J.and Crouch, S. (1977).Spectrophotometeric and kinetics investigation of the berthelot reaction for the determination of ammonia . Anal. Chem., 49: $464-469$.

Plock A ; W.Sokolowska-Kohler and W.Presber (2001).Effect of Saponins as a natural content harmful and anti nutritional factor. Experimental Parasitology 97,141-153.

Plohmann ,B.k ; G.L. Bader; K.R.Hiller and G.T.Franz (2008).enhancement effect to the Humeral immune response saponine on blood cells. Pharmazie 52, 953-957.

Reitman, S.and Frankle,S.(1957).A method for determination of plasma GOT and GPT. Am. J. Clin. Path., 28: 108.

Saleh,M.R.M.(2007).Potato by-products as animal feed.2-milk production and constituents and their effects on performance of new born lambs in lactating Rahmany ewes.J.Agric.Sci.Mansoura Univ.,32:4235-4245. SAS(2000).SAS/STAT Guide for Personal Computer.SAS inst.

Shehata E.I; M.E. Ahmed, A.M. Abdelhamid, Faten F. Abou Ammou, and M. $\mathrm{El}-\mathrm{H}$. Haggag (2001) Comparative nutritive values of silage ration containing different level of teosinte and kochia. Egyptian J. Nutrition and Feeds, (4):129.

Soliman,A.S ;M.SD.Gado and M.H.Abu El-Fadi (1995).Factors effecting milk yield and composition in fresian $X$ Balady cross bred cows. EgyptianJ.Appl.SCI.,10:601.M.Sc.Thesis,Fac.OFagric .,Tanta Univ.

Soliman,A.M.A.(1997).Ensiling some farm by-products in feeding ruminants. M.Sc. Thesis, Fac.OF agric., Tanta Univ.

Sony ,V.K.and D.D.Sharma (1982).Influence of levels of concentrate feeding on the microbial population in goat rumen Indian.J.Anim.Sci.,52(9) :821- 833 .

Steel ,W.(1980).The effect of soybeen meal and type of forage in the diet on the plasma lipid composition of sheep .Br.J.Nutr. 44: 333.

Story ,J.E.(1981). The effect of dietary fat on milk composition . Recent Advances in Animal Nutrition ( W.Haresign . Ed) pp3-33. 
Thomas, C.; K. ston and S.R. Daley (1985). Milk production from red clover with grass silage. Anim. Prod. 41:23-31.

Warner,A.G.T.(1964). Production of volatile fatty acids in the rumen Methods of mesurment . Nutr. Abstr. And Rev., 34:339 .

Weichselbaum,(1989).Colorimetric determination of total protein.Anim.J. PATH., 16:40.

Weimer, P.J.;G.C. waghorn ; D.R. Metens (1999). Effect of diet on population of three species of ruminal cellulolytic bacteria in lactating ruminants .J.Dairy Sci.,82:122.

Zeid, A. M.;E.I.Shehata and A.M. Abd-El-Gawad (2009).Growth performance of male Zaraibi goats fed green forages silage in their rations diffe- ring in roughage:concentrate ratio.J.Agric.Mansoura univ.34(11): 10441.

Yacout , M.H.M. and A.Y.El-Badawi , (2001).Effect of dietary protein level on fattening performance of animal calves. Egyptian . J.Nutrition and feeds 4 ( special issue ) : 545 - 556.

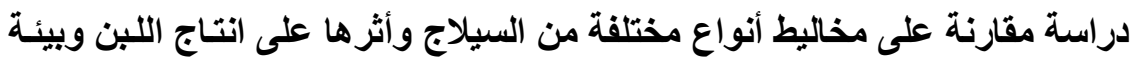

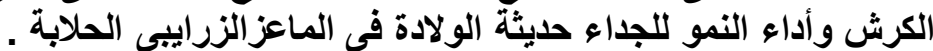

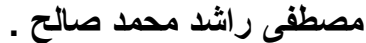

$$
\begin{aligned}
& \text { معهد بحوث الإنتاج الحيواني ـ مركز البحوث الزراعية ـ ـ دقي ـ مصر . }
\end{aligned}
$$

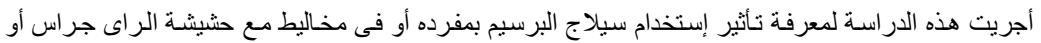

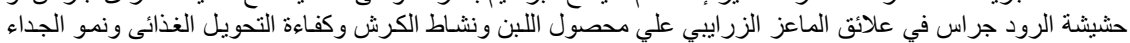

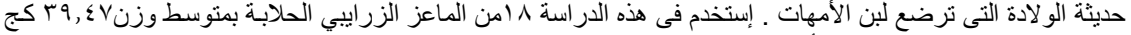

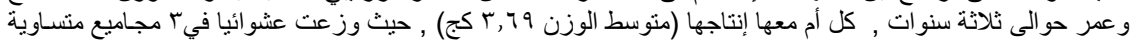

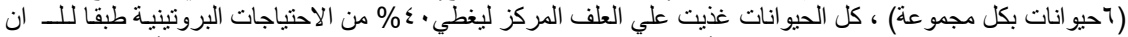

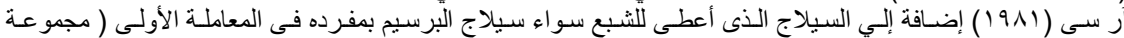

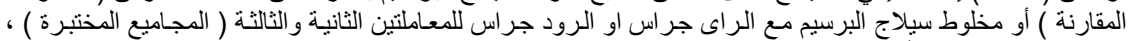

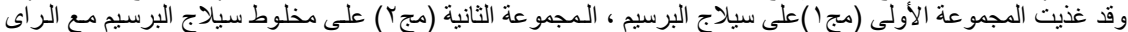

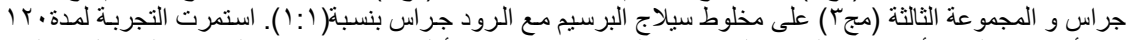

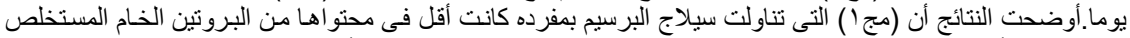

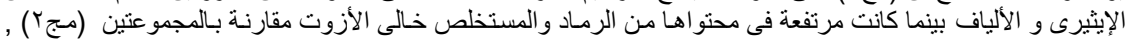

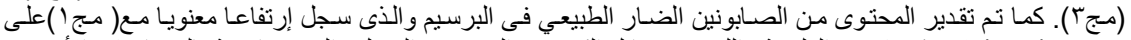

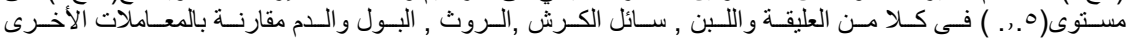

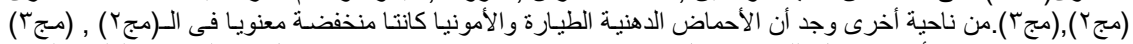

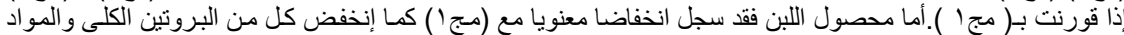

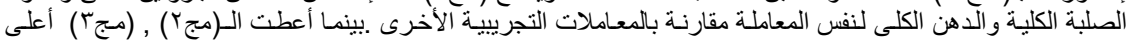

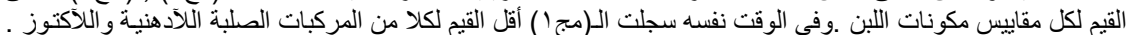

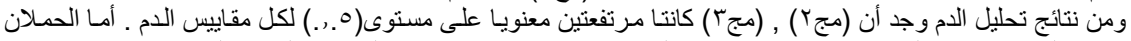

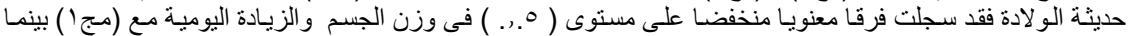

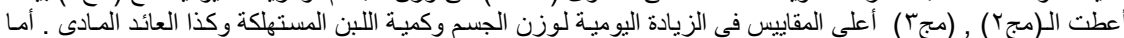

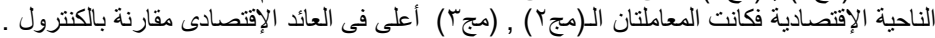

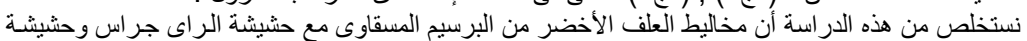

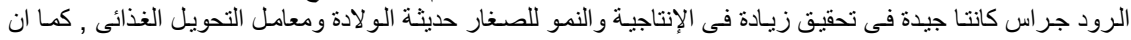

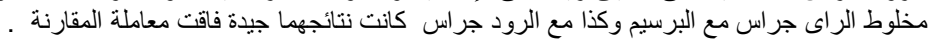

